\title{
FASILITAS PENELITIAN MULTIDISIPLIN UNTUK INOVASI LANJUT UNIVERSITAS TARUMANAGARA
}

\author{
Rene Matthew Sabian Djaya ${ }^{1)}$, Suwardana Winata ${ }^{2)}$ \\ 1)Program Studi S1 Arsitektur, Fakultas Teknik, Universitas Tarumanagara, matthewsabian@live.com \\ 2) Program Studi S1 Arsitektur, Fakultas Teknik, Universitas Tarumanagara, danarsitek@gmail.com
}

\begin{abstract}
Abstrak
Generasi yang sedang peran besar di masa depan, yaitu Generasi Y, juga dipanggil dengan "Millennials" adalah generasi kritis yang gemar mempelajari hal baru. Sering pula dikaitkan dan juga sangat mengapresiasi teknologi dan hubungan sosial. Generasi ini telah dibentuk oleh pengaruh-pengaruh budaya teknologi yang unik, yang sangat penting untuk dipikirkan dalam segala aspek khususnya dalam hal ber inovasi. Untuk mencapai hal tersebut, motivasi terhadap pengembangan dan penelitian demi penelitian harus sudah sering dilakukan, dari interaksi antara peneliti dan penggunanya, sampai campur tangan antar disiplin yang dalam hal ini, arsitektur memegang peranan yang cukup berpengaruh. Supaya sebuah penelitian dapat berhasil, dibutuhkan pengertian dan apresiasi dari kebutuhan, latar belakang, ketertarikan, dan pendekatan dari penelitinya, yang dalam setting penelitian seperti sekarang ini, seperti contohnya di Indonesia, sebagian besar sebuah disiplin ilmu hanya bergerak dari pengalaman dan pengembangan satu sampai dua disiplin saja. Hal itu yang menyebabkan sulit berkembangnya Inovasi dan teknologi seperti sekarang ini, ditambah kurangnya dukungan pemerintah dan institusi-institusi yang memfasilitasinya. Di era modern ini, caracara lama tentu tidak akan dapat lagi dapat dilanjutkan akibat perubahan yang telah terjadi, tentunya tidak melupakan standard dalam arsitektur di Indonesia, yang sudah harus mampu beradaptasi dan berinovasi terhadap berkembangnya zaman.
\end{abstract}

Kata kunci: inovasi; milenial; penelitian; teknologi

\begin{abstract}
The generation that is playing a big role in the future, namely Generation $Y$, also called "Millennials" is a critical generation that likes to learn new things. It is also often associated and also highly appreciates technology and social interactions. This generation has been shaped by the influences of unique technological cultures, which are very important to think about in every aspects, especially in terms of innovation. To achieve this, motivation for development and research for the sake of research must have been carried out frequently. Architecture plays an influential role in interactions between researchers and users, to multidisciplinary interference. In order for a study to succeed, it requires understanding and appreciation of the needs, background, interests, and approaches of the researchers, which in the current research setting, for example in Indonesia, most of the disciplines only move from one to two experiences and development just discipline. This is what causes the development of innovation and technology to be difficult as it is today, plus the lack of government support and institutions that facilitates it. In this modern era, the old ways will certainly no longer be able to continue due to the changes that have occurred, while not forgetting the standards of architecture in Indonesia, which must be able to adapt and innovate in this modern era.
\end{abstract}

Keywords: innovation; milenials; research; techonology

\section{PENDAhUluan}

Banyak hal yang telah berubah akibat dari berkembangnya teknologi, seperti salah satunya cara kita berinteraksi, berbelanja, bersosialisasi, dan semacamnya. Tentu tidak melupakan perubahan yang sedang terjadi di salah satu dunia yang penting di kehidupan manusia, yaitu Dunia Sains dan Teknologi. Di era modern ini, cara-cara dan metode lama tentu tidak akan dapat lagi dapat dilanjutkan akibat perubahan yang telah terjadi, tentunya tidak melupakan standard-standard dalam arsitektur yang sudah cukup ketinggalan zaman, seperti standardstandard yang telah dibuat berdekade-dekade lamanya. Dengan terus berkembangnya 
teknologi dan penemuan-penemuan baru, tentunya cara dan gaya dalam menelitipun tentunya harus tetap mampu beradaptasi terhadap pekembangannya. Oleh sebab itu, dibutuhkannya sebuah model laboratorium yang dapat menciptakan lingkungan lab yang responsif terhadap kebutuhan saat ini dan mampu mengakomodasi kebutuhan permintaan masa depan. Laboratorium di seluruh dunia menyediakan lingkungan berteknologi tinggi yang diperlukan oleh para peneliti untuk menemukan cara terapi medis yang inovatif, membuat kemajuan di dunia pertanian, dan mengembangkan pendekatan inovatif untuk tantangantangan besar di dunia. Laboratorium yang baik adalah hasil dari kolaborasi, dan koordinasi yang luas antara tim peneliti dan semua bagian yang berkepentingan. Bahkan detail terkecil, yang dilakukan secara tidak benar, dapat berdampak buruk pada fungsi dan keselamatan lab jadi, mendapatkan ruang yang tepat untuk para ilmuwan yang bekerja di dalamnya sangat penting.

Terdapat rumusan masalah sebagai berikut:

- Di Indonesia sendiri, perkembangan di dunia penelitian cenderung masih bersifat satu disiplin saja. Kurangnya fasilitas penelitian dan kolaborasi antar disiplin di indonesia membuat sulitnya perkembangan didunia teknologi dan inovasi.

- Kurangnya campur tangan dari pemerintah serta kurangnya minat dari para generasi milenial untuk menelusur kembali inti dari pengetahuan untuk menambah wawawasan dan inovasi ini membuat kolaborasi antar disiplin menjadi kurang berkembang di Indonesia. Fasilitas penelitian multidisiplin selayaknya dibuat agar kerjasama antar disiplin dapat dilakukan dan tercipta sebab untuk mencapai sebuah tujuan tertentu dibutuhkan kerja sama dan kolaborasi.

Untuk mencapai sebuah tujuan dalam perkembangan dan inovasi teknologi, diperlukan kolaborasi dan kerjasama antar disiplin serta diskusi-diskusi ilmiah secara terus menerus serta diperlukannya pula pengajaran-pengajaran serta latihan baik secara langsung maupun secara bertahap.

- Bagaimana cara untuk mengadakan sebuah kolaborasi antar disiplin untuk terciptanya sebuah inovasi?

- Bagaimana cara membangkitkan rasa ketertarikan para Milenial akan penelitian dan inovasi?

Terdapat tujuan penelitian sebagai berikut:

- Mengkolaborasikan kerjasama antar disiplin ilmu agar terciptanya inovasi dan perkembangan akan pengetahuan dan terciptanya penemuan-penemuan baru.

- Membangkitkan rasa percaya diri pada Milenial dengan menyediakan sebuah fasilitas yang mendukung sebuah inovasi dan penelitian.

- Membangun sebuah fasilitas Penelitian Multidisiplin untuk Universitas Tarumanagara untuk memberikan fasilitas dalam penelitian demi menghadapi tantangan-tantangan di masa depan.

Terdapat manfaat penelitian sebagai berikut:

- Inovasi dan pengembangan akan lebih tercipta dalam lingkungan pendidikan yang lebih luas secara jelas dan terstruktur.

- Penemuan-penemuan yang terjadi dalam negeri-pun akan mampu bertambah dan dapat diakui serta dapat berkolaborasi di luar negeri.

- Para milenial baik saat ini maupun saat mendatang tidak perlu lagi bergantung pada inovasi yang diberikan oleh negara-negara berkembang lain namun dapat secara pecaya diri dan bangga akan penemuan yang ditemukan dalam negeri. 
Terdapat sistematika pembahasan penelitian sebagai berikut:

Tahap Pertama Pendahuluan

- Tentang latar belakang alasan proyek tujuan dan manfaat, batasan ruang lingkup dan metode pembahasan yang digunakan

Tahap Kedua Kajian Teoritikal

- Tentang bagaimana menjelaskan hal-hal yang terkait dengan usulan proyek arsitektur dengan menggunakan teori sebagai analisis dan menguraikan usulan proyek sesuai tema Architourism Metropolis

Tahap Ketiga Permasalahan

- Menguraikan cara bagaimana tentang kompleksitas proyek, menjelaskan permasalahan yang dihadapi dengan usulan yang akan di terapkan

Tahap keempat Analisis

- Menganalisis tentang program yang di kembangkan, kebutuhan, lokasi dan analisi studi preseden.

Terdapat Problematika Desain penelitian sebagai berikut:

\section{Perkotaan}

- Intensitas Bangunan

- Aksesibilitas Menuju Tapak.

- Kepadatan Penduduk

- Peruntukan, Jaringan dan Utilitas

Lingkungan

- Pengaturan Parkir dan Ruang Terbuka

- Potensi Lingkungan dan Kondisi Lingkungan

- Pengaturan Sirkulasi, Pencapaian Tapak

Bangunan

- Penyesuaian Bangunan dan Benuk Kebudayaan

- Pengolohan Bentuk Massa, Penampilan Bangunan dan Perlengkapan Bangunan

- Panggung, Lighting dan Teknologi

Kegiatan

- Sirkulasi Kegiatan

- Penggabungan Berbagai Kegiatan

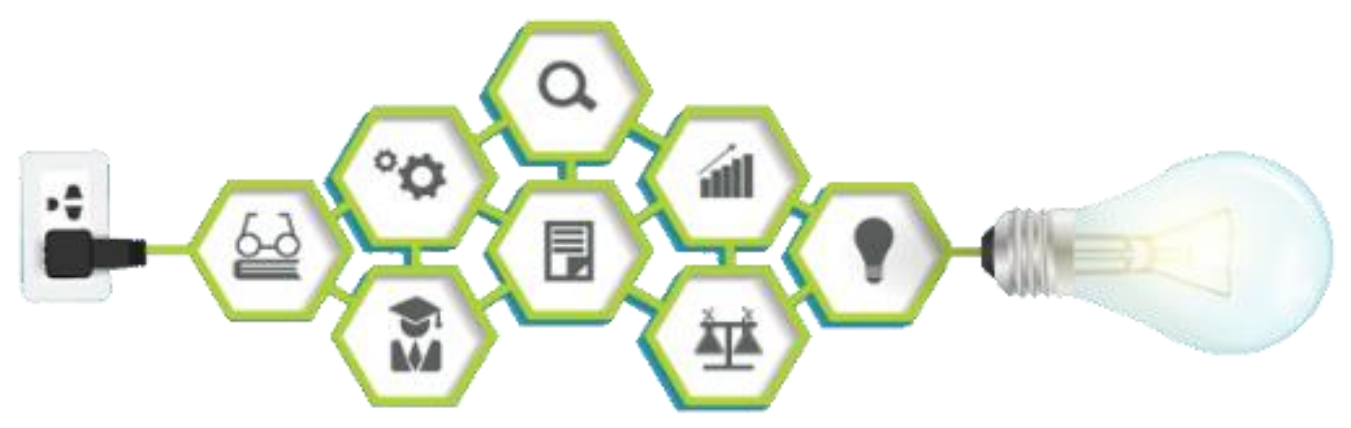

Gambar 1. Proses Inovasi

Sumber: https://www.sopheon.com/establishing-an-effective-innovation-processarchitecture/ 


\section{KAJIAN LITERATUR}

\section{Penelitian (Research)}

Penelitian adalah kegiatan akademik dan istilah tersebut harus digunakan dalam pengertian teknis. Menurut Clifford Woody (Kothari 1988), penelitian terdiri dari mendefinisikan dan mengartikan kembali masalah, merumuskan hipotesis atau solusi yang disarankan; mengumpulkan, mengatur, dan mengevaluasi data; membuat deduksi dan mencapai kesimpulan; dan akhirnya dengan hati-hati menguji kesimpulan untuk menentukan apakah mereka cocok dengan hipotesis yang dirumuskan. D. Slesinger dan M. Stephenson (1930) dalam Ensiklopedia Ilmu Sosial mendefinisikan penelitian sebagai "manipulasi hal-hal, konsep atau simbol untuk tujuan generalisasi untuk memperluas, memperbaiki atau memverifikasi pengetahuan, apakah pengetahuan itu membantu konstruksi teori atau dalam praktik sebuah seni." Dengan demikian, penelitian merupakan kontribusi asli terhadap cadangan pengetahuan yang ada untuk kemajuannya. Ini adalah pengejaran kebenaran dengan bantuan studi, observasi, perbandingan, dan eksperimen. Singkatnya, pencarian pengetahuan melalui metode objektif dan sistematis untuk menemukan solusi untuk suatu masalah adalah penelitian. Pendekatan sistematis mengenai generalisasi dan perumusan teori juga merupakan penelitian. Dengan demikian istilah 'penelitian' mengacu pada metode sistematis yang terdiri dari mengutarakan masalah, merumuskan hipotesis, mengumpulkan fakta atau data, menganalisis fakta-fakta dan mencapai kesimpulan tertentu baik dalam bentuk solusi (s) terhadap masalah yang bersangkutan atau dalam generalisasi tertentu untuk beberapa formulasi teoritis.

\section{Tujuan Penelitian}

Tujuan dari penelitian ini adalah untuk menemukan jawaban atas pertanyaan melalui penerapan prosedur ilmiah. Tujuan utama penelitian adalah untuk menemukan kebenaran yang tersembunyi dan yang belum ditemukan. Meskipun setiap studi penelitian memiliki tujuan spesifiknya sendiri, kami menyebutkan beberapa tujuan umum dari penelitian di bawah ini:

a. Untuk mendapatkan keakraban dengan suatu fenomena atau untuk mencapai wawasan baru ke dalamnya (studi dengan objek ini dalam pandangan disebut sebagai studi penelitian ekspatoris atau formatif;

b. Untuk menggambarkan secara akurat karakteristik individu, situasi atau kelompok tertentu (studi dengan objek ini dalam pandangan dikenal sebagai studi penelitian deskriptif);

c. Untuk menentukan frekuensi di mana sesuatu terjadi atau yang dikaitkan dengan sesuatu yang lain (studi dengan objek ini dikenal sebagai studi penelitian diagnostik);

d. Untuk menguji hipotesis tentang hubungan kausal antara variabel (studi tersebut dikenal sebagai studi penelitian pengujian hipotesis).

\section{Jenis-jenis Penelitian}

Jenis dasar penelitian adalah sebagai berikut:

a. Deskriptif vs. Analitik: Penelitian deskriptif mencakup survei dan pertanyaan pencarian fakta dari berbagai jenis. Tujuan utama dari penelitian deskriptif adalah deskripsi keadaan yang ada saat ini.

b. Terapan vs. Mendasar: Penelitian terapan bertujuan menemukan solusi untuk masalah langsung yang dihadapi masyarakat atau organisasi industri / bisnis, sedangkan penelitian mendasar berkaitan dengan generalisasi dan dengan perumusan teori. Mengumpulkan pengetahuan demi pengetahuan disebut penelitian dasar. Penelitian tentang beberapa fenomena alam atau yang berkaitan dengan matematika murni adalah contoh penelitian mendasar.

c. Kuantitatif vs. Kualitatif: Penelitian kuantitatif didasarkan pada pengukuran kuantitatif beberapa karakteristik. Ini berlaku untuk fenomena yang dapat dinyatakan dalam jumlah. Penelitian kualitatif, di sisi lain, berkaitan dengan fenomena kualitatif, yaitu, fenomena yang berkaitan dengan atau melibatkan kualitas atau jenis. 
d. Konseptual vs Empiris: Penelitian konseptual adalah yang terkait dengan beberapa ide atau teori abstrak. Pada umumnya metode ini digunakan oleh para filsuf dan pemikir untuk mengembangkan konsep-konsep baru atau untuk menafsirkan kembali yang sudah ada. Di sisi lain, penelitian empiris bergantung pada pengalaman atau pengamatan saja, seringkali tanpa memperhatikan sistem dan teori. Ini adalah penelitian berbasis data, menghasilkan kesimpulan yang mampu diverifikasi dengan observasi atau eksperimen.

e. Beberapa Jenis Penelitian Lainnya: Semua jenis penelitian lainnya adalah variasi dari satu atau lebih pendekatan yang disebutkan di atas, berdasarkan pada tujuan penelitian, atau waktu yang diperlukan untuk menyelesaikan penelitian, pada lingkungan di mana penelitian dilakukan, atau atas dasar beberapa faktor serupa lainnya. Dari sudut pandang waktu, kita dapat menganggap penelitian sebagai penelitian satu kali atau penelitian longitudinal. Dalam kasus sebelumnya, penelitian dibatasi pada satu periode waktu saja, sedangkan dalam kasus yang terakhir penelitian dilanjutkan beberapa periode waktu. Penelitian ini dapat berupa penelitian lapangan atau penelitian laboratorium atau penelitian simulasi, tergantung pada lingkungan di mana ia akan dilakukan.

\section{Laboratorium}

Laboratorium adalah fasilitas yang menyediakan kondisi terkendali di mana penelitian, eksperimen, dan pengukuran ilmiah atau teknologi dapat dilakukan. Laboratorium yang digunakan untuk penelitian ilmiah mengambil banyak bentuk karena persyaratan yang berbeda dari para spesialis di berbagai bidang sains dan teknik. Laboratorium fisika mungkin berisi akselerator partikel atau ruang hampa udara, sedangkan laboratorium metalurgi dapat memiliki peralatan untuk casting atau pemurnian logam atau untuk menguji kekuatan mereka. Seorang ahli kimia atau ahli biologi mungkin menggunakan laboratorium basah, sedangkan laboratorium psikolog mungkin merupakan ruangan dengan cermin satu arah dan kamera tersembunyi untuk mengamati perilaku. Di beberapa laboratorium, seperti yang biasa digunakan oleh para ilmuwan komputer, komputer (kadang-kadang superkomputer) digunakan untuk simulasi atau analisis data. Ilmuwan di bidang lain masih akan menggunakan jenis laboratorium lain. Insinyur menggunakan laboratorium juga untuk merancang, membangun, dan menguji perangkat teknologi.

Laboratorium ilmiah dapat ditemukan sebagai ruang penelitian dan ruang belajar di sekolah dan universitas, industri, pemerintah, atau fasilitas militer, dan bahkan di atas kapal dan pesawat ruang angkasa.

\section{Tipe Laboratorium}

Secara paling mendasar dalam mendesain Laboratorium, menurut website "Whole Building Design Guide" dibagi menjadi dua tipe kategori, yaitu Laboratorium Basah dan Laboratorium Kering.

a. Laboratorium Basah

Jenis ruang Laboratorium Basah didefinisikan sebagai laboratorium di mana bahan kimia, obat-obatan, atau materi biologis lainnya diuji dan dianalisis menggunakan air, ventilasi langsung, dan utilitas pipa khusus. Jenis ruang Laboratorium Basah tidak termasuk biohazard di Level BL-2, BL-3, dan BL-4 sebagaimana didefinisikan oleh pedoman NIH / CDC 2007 "Keamanan Hayati dalam Laboratorium Mikrobiologi dan Biomedis (BMBL) Edisi ke-5". Jenis ruang Laboratorium Basah biasanya terletak di dalam bangunan yang dirancang khusus untuk menampungnya. Jenis-jenis ruang Laboratorium Basah cukup unik karena mereka harus mengakomodasi ventilasi dan sambungan utilitas secara simultan dan terpisah pada masing-masing modul laboratorium untuk memastikan keandalan dan keakuratan hasil serta keselamatan penghuni di seluruh ruang.

b. Laboratorium Kering

Jenis ruang Laboratorium Kering adalah ruang laboratorium yang khusus untuk bekerja 
dengan bahan yang disimpan kering, elektronik, dan / atau instrumen besar dengan sedikit layanan perpipaan. Laboratorium yang ditentukan oleh tipe ruang ini adalah laboratorium analitik yang mungkin memerlukan kontrol suhu dan kelembaban yang akurat, kontrol debu, dan daya bersih. Jenis ruang laboratorium kering dirancang untuk mengakomodasi pola kerja spesifik proyek dan peralatan ilmiah. Karena itu, mereka cenderung menyertakan fitur desain yang menyediakan kondisi kerja yang dapat diandalkan di lingkungan dengan tingkat mobilitas tinggi.

\section{METODE}

Dalam metode penelitian menggunakan metode riset dengan menganalisa kebutuhan, permasalahan yang dihadapi dalam tapak serta berpusat terhadap penelitian apa yang akan dilakukan serta implementasinya dalam desain.

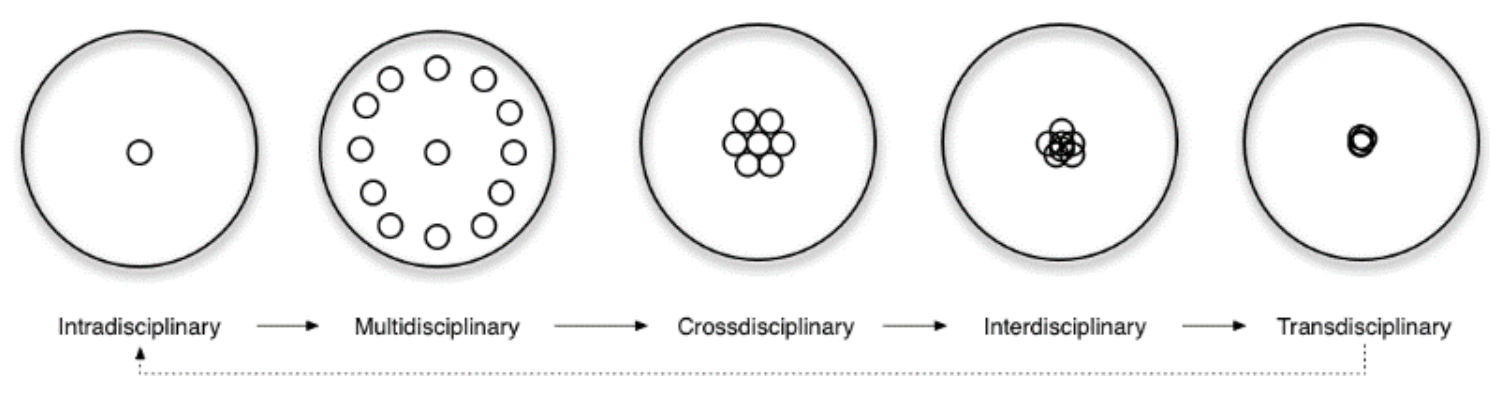

Gambar 2. Macam Penelitian

Sumber: researchgate.net

Dengan datang langsung ke lokasi untuk melihat keadaan di lapangan secara langsung, observasi dan mengumpulkan data-data yang berkaitan dengan fasilitas penelitian dan juga keadaan lokasi, tidak hanya metode lapangan yang digunakan melainkan pemanfaatan bukubuku dan juga internet yang berhubungan dengan penelitian yang akan di kerjakan di manfaatkan untuk tujuan mengambil informasi secara menyeluruh. Metode-metode yang digunakan bertujuan untuk menyempurnakan hasil survey yang di ketahui sebelum mengerjakan tugas arsitektur yang akan dikerjakan.
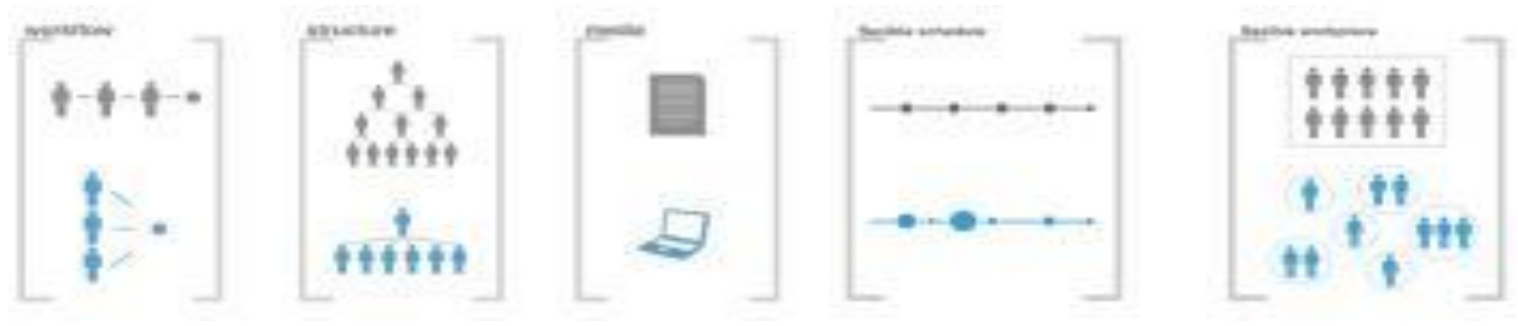

Gambar 3. Sistem Kerja Milenial

Sumber: google.images. 


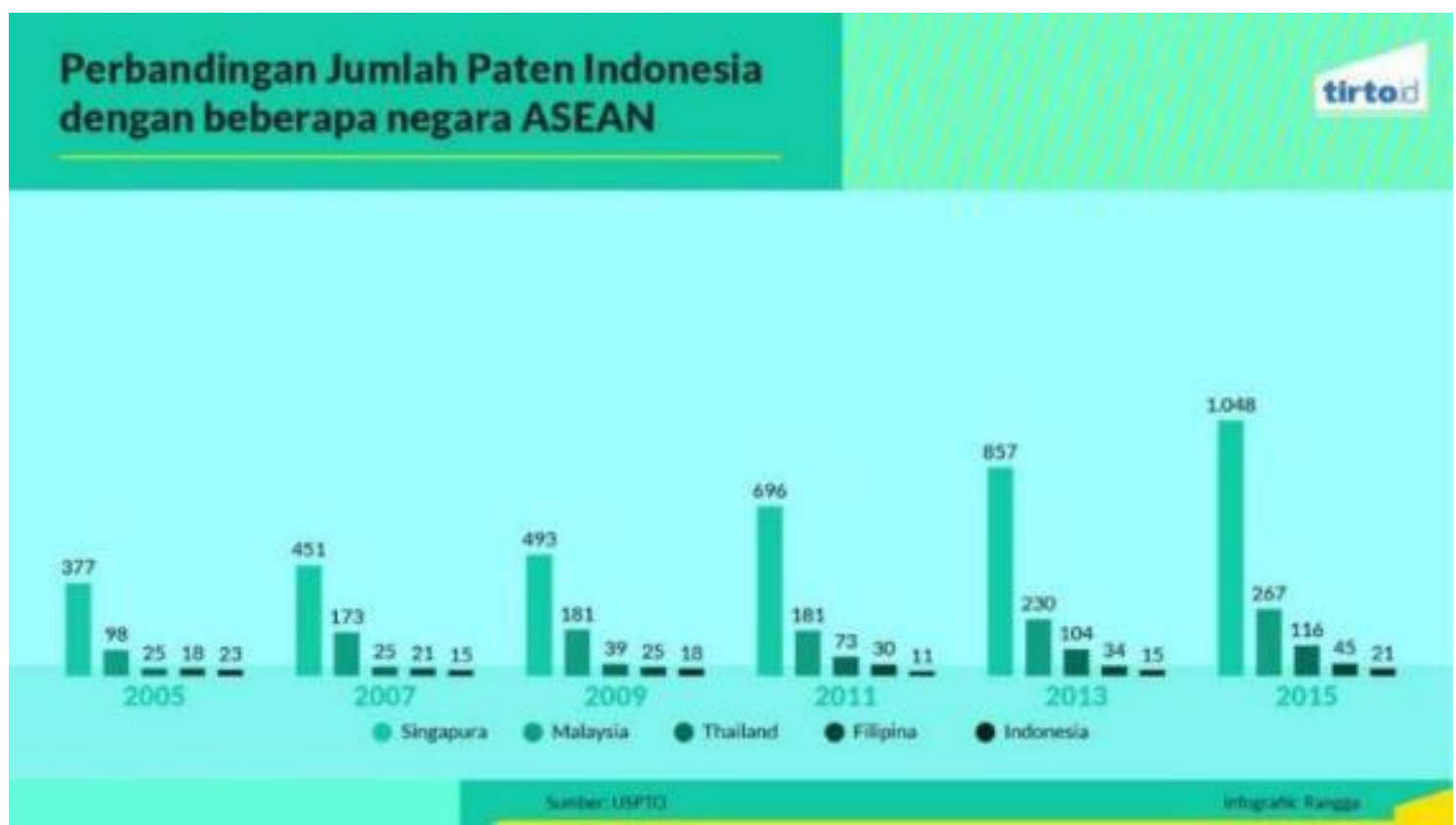

Gambar 3. Perbandingan Jumlah Paten Indonesia dengan beberapa negara ASEAN Sumber: tirto.id

\section{DISKUSI DAN HASIL}

\section{Millennials}

Istilah Millennial umumnya mengacu pada generasi orang yang lahir antara awal 1980-an dan 1990-an, menurut Kamus Merriam-Webster. Beberapa orang juga memakai istiliah ini pada anak-anak yang lahir pada awal tahun 2000-an. Generasi Milenial juga dikenal sebagai Generasi Y, karena generasi ini muncul setelah Generasi $X$, yaitu orang-orang yang hidup antara awal 1960-an dan 1980-an. Artikel dari Publikasi Ad Age (1993) adalah salah satu publikasi yang pertama kali menciptakan istilah "Generasi $Y, "$. Namun, istilah tersebut terlupakan, dan istilah "Millenial" lah yang akhirnya lebih sering digunakan. Tetapi istilah ini pada dasarnya memiliki arti yang sama (Bennett et al, 2008, Wessner and Miller, 2008).

\section{Tipe, Karakteristik}

Generasi Millenial telah dikarakterisasi dalam sejumlah cara berbeda. Secara general, apabila dilihat dari sisi negatif, mereka digambarkan sebagai pemalas, konsumtif, narsis dan memiliki rentan perhatian yang singkat. Namun apabila dilihat dari sisi positif, Mereka umumnya dianggap lebih berpikiran terbuka, percaya diri, ekspresif, dan menerima ide-ide baru dengan baik (Hershatter \& Eppstein, 2010). Dan apabila dijelaskan dengan lebih rinci, beberapa karakteristik yang terbentuk sesuai dengan berkembangnya teknologi, seperti yang dikutip dari salah satu tulisan karya Micah Solomon adalah;

\section{A. Teknologi merupakan bagian dari hidup dan sudah selayaknya difungsikan}

Generasi Milenial tumbuh dengan perangkat digital yang menggabungkan komunikasi, hiburan, belanja, dan pendidikan semuanya dalam satu alat. Sejak usia dini, penggunaan smartphone telah menjadi hal wajar. Milenial selalu memiliki internet di rumah dan di sekolah. Lalu terjadi secara alami, milenial merangkul dan menyesuaikan diri dengan teknologi, oleh sebab itu milenial cenderung lebih mengadopsi teknologi baru dengan cepat dibandingkan dari generasi sebelumnya. Teknologi telah menjadi jauh lebih ramah pengguna selama masa hidup milenial, khususnya bila dibandingkan dengan apa yang ditemui generasi sebelumnya (Hershatter \& Epstein, 2010). 


\section{B. Generasi Sosial}

Generasi Milenial adalah generasi yang mudah bergaul. Dan untuk mereka, pergaulan dapat diungkapkan secara online maupun juga dalam kehidupan nyata, seperti banyak tempat dimana lingkaran pertemanan online maupun offline saling bertemu. Di kehidupan nyatapun, milenial lebih suka berbelanja, makan, maupun jalan-jalan bersama kawan-kawannya dibanding generasi sebelumnya. Dikehidupan online, kebiasaan berbagi di Facebook, Snapchat dan situs sosial lainnya, atau memberikan pendapat mereka secara online seperti melalui aplikasi Zomato, TripAdvisor, dll., mencerminkan keinginan mereka untuk saling berkoneksi(Jones \& Fox, 2009).

\section{Gemar Berkolaborasi dan Bekerja sama}

Milenial gemar untuk bekerja bersama seperti dalam sebuah grup dibanding bekerja sendiri. Mereka lebih menyukai kepemimpinan dibanding bekerja dalam hirarki atau tingkatan. Mereka tidak suka terlihat berbeda secara individual, namun lebih ingin diperlihatkan sebagai bagian dari sebuah grup.

\section{Kawasan Grogol Petamburan}

Kecamatan Grogol Petamburan terletak di Jakarta Barat. Nama kecamatan ini diambil dari sungai Grogol. Di sini banyak terdapat sekolah-sekolah tinggi dan universitas-universitas ternama, di antaranya adalah Universitas Kristen Krida Wacana, Universitas Tarumanegara dan Universitas Trisakti, serta terdapat pula banyak perkantoran serta fasilitas lain seperti mall dan tempat-tempat untuk berkumpul para milenial, yang menjadikan kawasan ini strategis untuk mengadakan kolaborasi antar milenial dan peneliti.

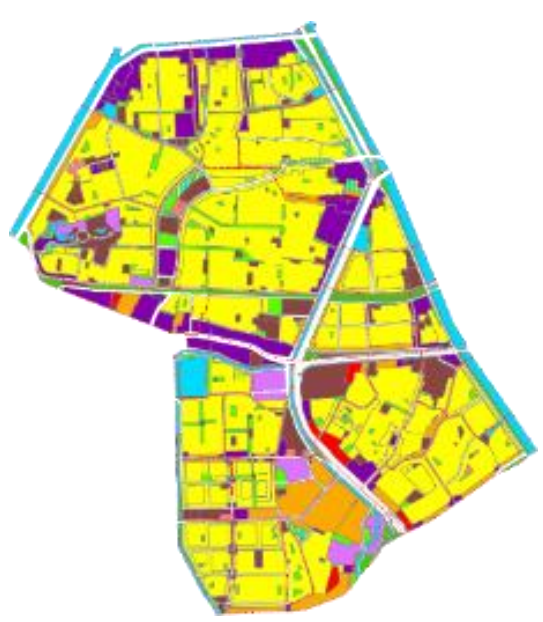

Gambar 4. Kawasan Grogol Petamburan

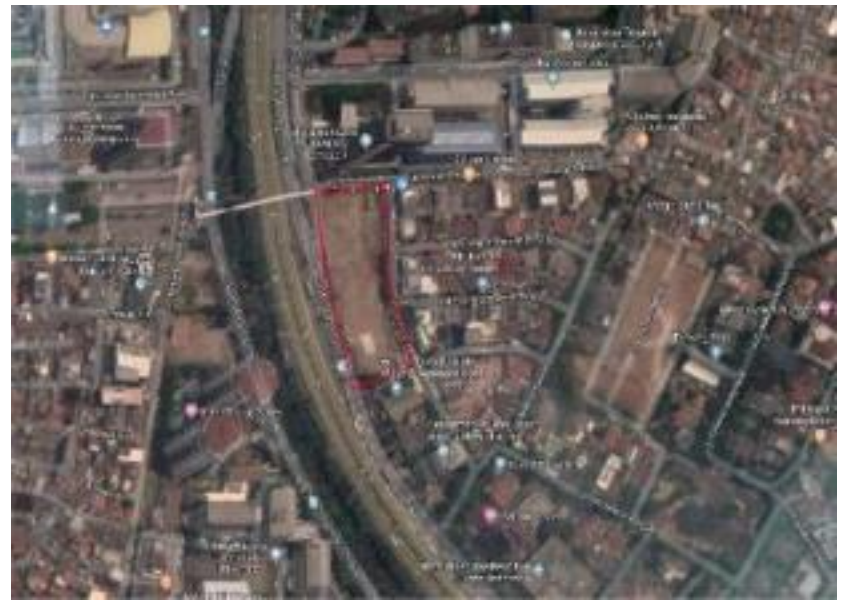

Gambar 5. Lokasi Tapak Sumber: Google Maps, 2019

Sumber: Tata Ruang Jakarta, 2019

Bedasarkan pengelolaan tata ruang, kawasan Grogol diperuntukan untuk menjadi kawasan Pendidikan namun terdapat juga peruntukan lain untuk melengkapi kebutuhan kawasan tersebut menurut zonasi ruang seperti sub zona campuran dan sub zona hunian. Pada site di Grogol yang terletak di jalan Letjen. S. Parman, tapak atau site memiliki KDB:50\% KLB :3.50 KB:16 KDH:30 KTB:55\% dengan luas lahan $8268.21 \mathrm{~m} 2$ dengan keadaan lahan masi kosong serta bersebelahan langsung dengan Universitas Tarumanagara.

Kawasan Grogol memiliki beberapa akses yang dapat di tempuh menggunakan jalan kaki dan juga kendaraan yang nantinya akan menjadi prinsip dan juga masalah yang akan di pecahkan pada saat pemilihan site yang tepat di Kawasan ini. 


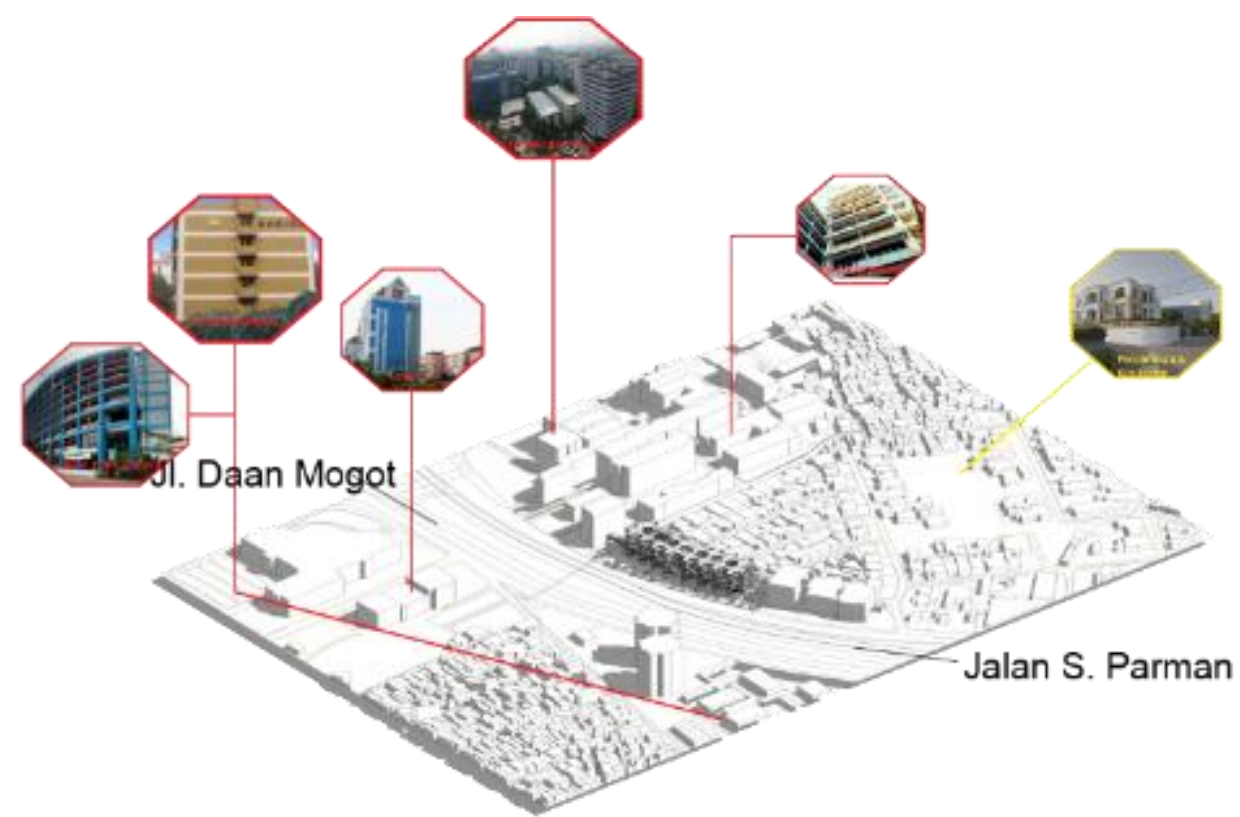

Gambar 6. Mapping Kawasan Sekitar Tapak Sumber: Penulis, 2019

- Lokasi berada di dekat lingkungan Pendidikan dan Perkantoran. Lokasi berdekatan dengan pendidikan dan perkantoran di jakarta yang dapat mendukung kegiatan komunitas didalamnya.

- Lokasi mempunyai daya tarik karena bersebelahan dengan Universitas Tarumanagara.

- Lokasi menunjang adanya fungsi kuliner dan komunitas melihat banyaknya zona perumahan dan perkantoran yang ada sebagai tempat berkumpulnya milenial sebagai target pasar.

- Lokasi mempunyai akses transportasi publik yang cukup baik untuk mencapai tapak mulai dari Bus Transjakarta, Bus feeder, dll.

\section{Fasilitas Penelitian Multidisiplin}

Fasilitas Penelitian Multidisiplin pertunjukan merupakan suatu tempat yang dipergunakan untuk dapat mengakomodasi dan memberikan fasilitas dalam hal keamanan serta fungsi untuk dilakukannya proses penelitian ilmiah yang dalam hal ini penlitian antar displin satu maupun disiplin lainnya. Fungsi dari sebuah laboratorium berbanding lurus dengan penelitian apa yang akan dilakukan didalamnya, namun seiring dengan berkembanya zaman dan teknologi, banyak pula ilmu-ilmu yang berkembang yang seharusnya dapat berkolaborasi antar satu maupun disiplin lainnya. Tujuan dibangunnya gedung yang menyediakan fasilitas laboratorium untuk dilakukannya penelitian ini karena kurangnya fasilitas yang menyediakan kolaborasi antar disiplin-disiplin ilmu lainnya untuk mampu bekerja sama dalam mencapai sebuah inovasi yang ada di Indonesia. Fasilitas penelitian yang sudah ada biasanya hanya mewadahi satu bidang saja dalam bangunan yang sama maupun terpisah. Sebuah gedung Fasilitas penelitian selain berfungsi dan digunakan untuk melakukan penelitian, namun sebaiknya harus mampu memfasilitasi kolaborasi antar disiplin ilmu untuk mengeksplorasi dan mencapai inovasi.

\section{Fasilitas Utama}

Bagaimana memfasilitasi penelitian antar disiplin ilmu pada era modern dengan Milenial? Dengan serta memfokuskan pada penelitian multidisiplin yang kolaboratif, serta dikemas secara modern dengan menyediakan banyak ruang-ruang untuk berdiskusi yang mampu 
memberikan aktifitas untuk berinteraksi dan menambah kreatifitas serta memberikan ruang untuk para peneliti dapat saling bertukar pikiran demi dicapainya sebuah inovasi.

- Menyediakan laboratorium yang menyediakan beberapa macam alat riset dengan penggabungan beberapa disiplin ilmu dalam lingkup yang dibatasi.

- Memberikan Laboratorium berbasis sebuah tim. Laboratorium harus memiliki alat-alat dan layanan teknis yang dapat dengan mudah diubah untuk mendukung setiap tim peneliti. Dengan berkembangnya jaman, laboratorium ini dapat dikonfigurasi menjadi laboratoriumlaboratorium khusus yang berbeda.

- Memberikan laboratorium-laboratorium generik, sebab ketika fasilitas laboratorium dirancang secara umum, semua laboratorium memiliki ukuran yang sama dan dilengkapi dengan layanan teknik dasar dan pekerjaan kasus yang sama. Laboratorium generik adalah pilihan yang masuk akal ketika tidak diketahui siapa yang akan menempati ruang tersebut atau jenis penelitian spesifik apa yang akan dilakukan di sana. Desain lab generik juga masuk akal dari sudut pandang administratif, karena setiap tim atau peneliti diberikan fasilitas dasar yang sama. Laboratorium generik terbaik memiliki fleksibilitas yang tertanam di dalamnya dan dapat dengan mudah dimodifikasi untuk pemasangan peralatan atau untuk perubahan pada layanan teknik atau kerja kasus. Banyak laboratorium baru yang dirancang dengan meja penelitian dengan tingkat mobilitas yang tinggi agar dapat beradaptasi.

\section{Fasilitas Penunjang}

Fasillitas-fasilitas penunjang diberikan dapat memberikan dan memancing para generasi milenial maupun generasi selanjutnya untuk berkreasi dalam hal inovasi serta tempat yang memberikan fasilitas untuk mengedukasi dan memancing kreatifitas.

- Memberikan ruang pameran/eksibisi untuk memamerkan hasil karya kolaboratif yang sudah dilakukan antar disiplin ilmu di fasilitas ini pada publik agar dapat memberikan motivasi pada para milenial-milenial lain untuk lebih berkarya secara kreatif dan kolaboratif demi menciptakan lebih banyak lagi inovasi-inovaasi serta memberikan kebanggaan atas hasil penemuan-penemuan yang sudah dilakukan.

- Memberikan fasilitas ruang belajar kolaboratif yang melibatkan mahasiswa di perguruan tinggi, yang masih sekolah maupun para profesional-profesional di dunia kerja agar dapat berkolaborasi sehingga proses ajar mengajar ilmu pengetahuan serta bertukar pengelaman dapat dilakukan secara terbuka meliputi lintas generasi.

- Menyediakan auditorium untuk memberikan dan membagikan pengetahuan multi disiplin agar menambah wawasan serta pengetahuan antar disiplin ilmu.

\section{Sasaran Proyek}

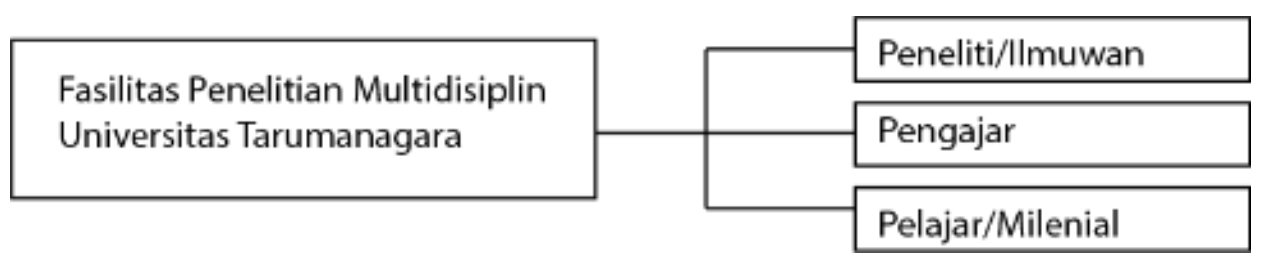

Gambar 7. Sasaran Proyek

Sumber: Penulis, 2019

Peneliti menjadi sasaran utama dalam Proyek Fasilitas Penelitian Multidisiplin ini, dilanjut dengat pengajar yang nantinya akan mampu menurunkan pengetahuan serta inovasi kepada generasi lanjut yang akan belajar dan berinovasi untuk masa yang akan datang seperti generasi $Z$ dan seterusnya. 


\section{Analisa Program Aktifitas}
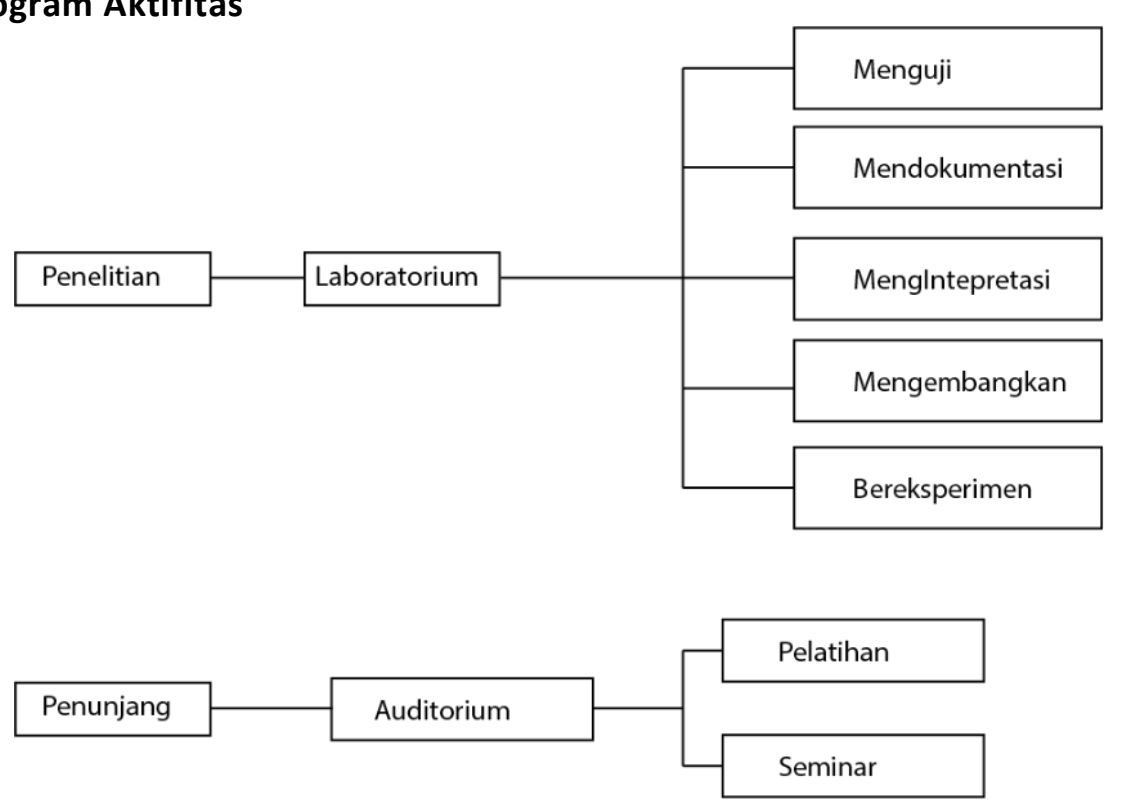

Gambar 8. Analisa Program Aktifitas

Sumber: Penulis, 2019

\section{Analisa Kawasan}

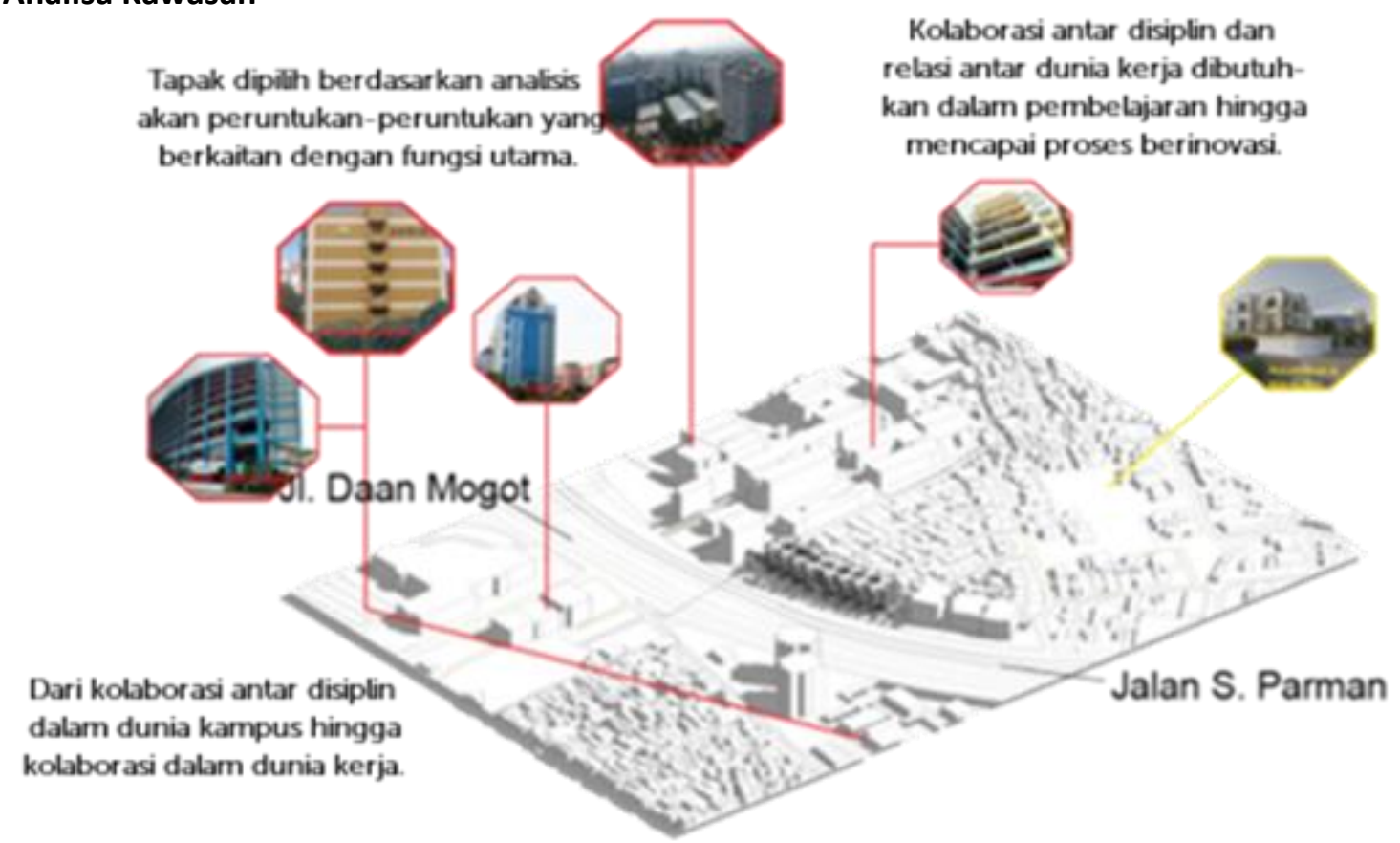

Gambar 9. Analisa Kawasan

Sumber: Penulis, 2019 


\section{Hasil Perancangan}

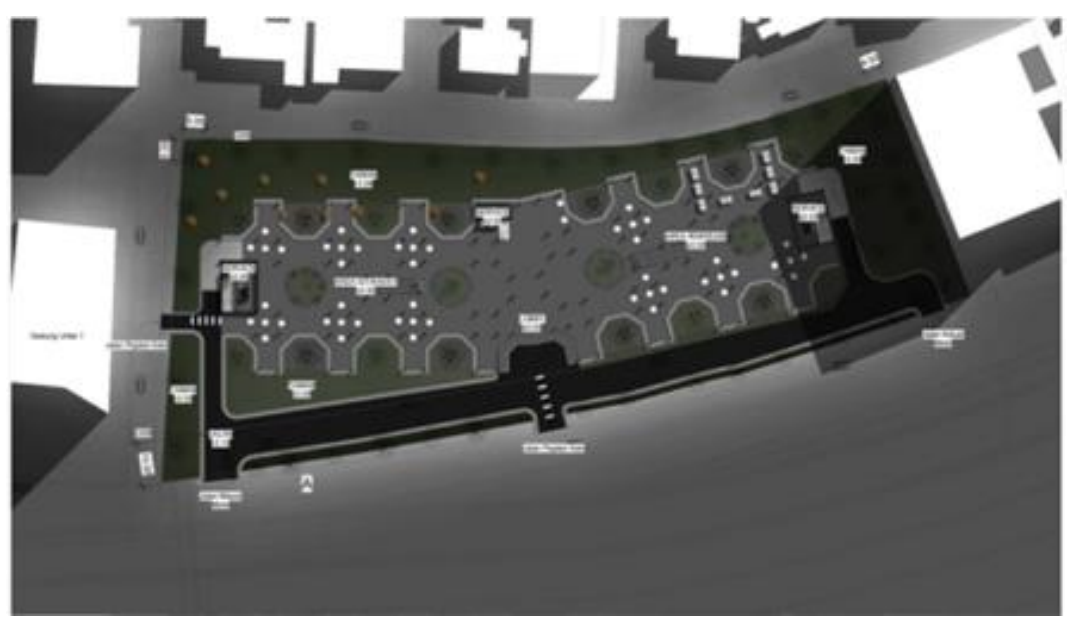

Gambar 10. Site Plan

Sumber: Penulis, 2019

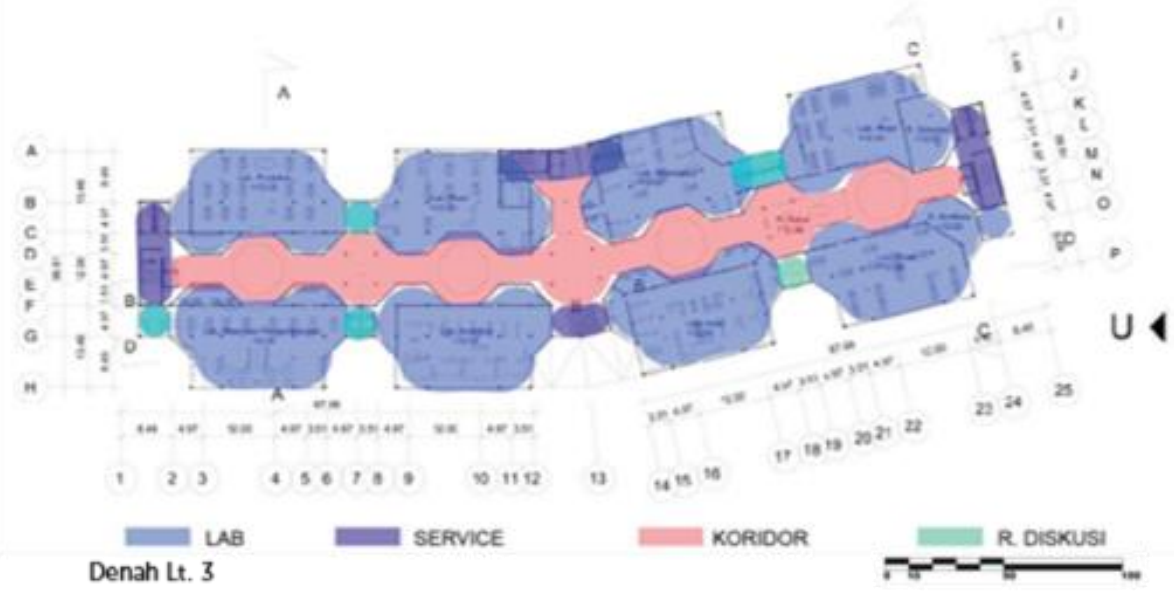

Gambar 11. Denah Lt. 3

Sumber: Penulis, 2019

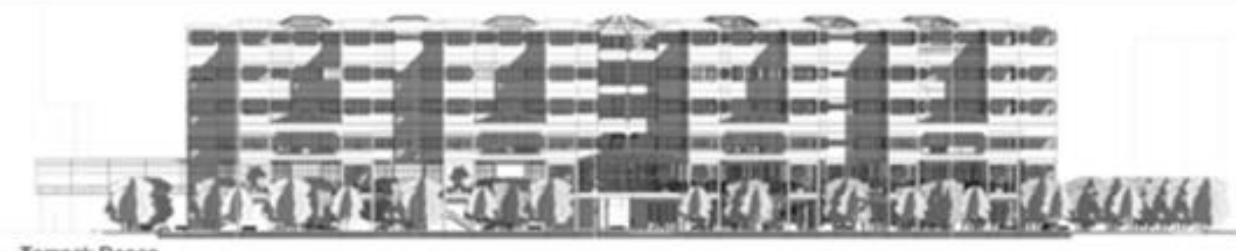

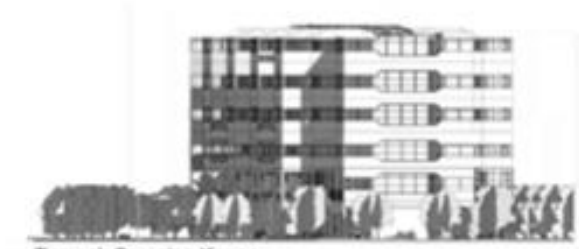

2 Tampak Samping Kanan

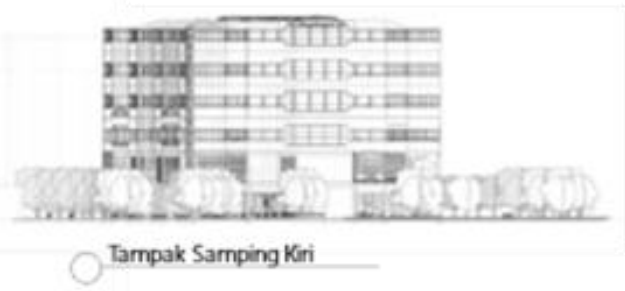

Gambar 12. Tampak Bangunan

Sumber: Penulis, 2019 


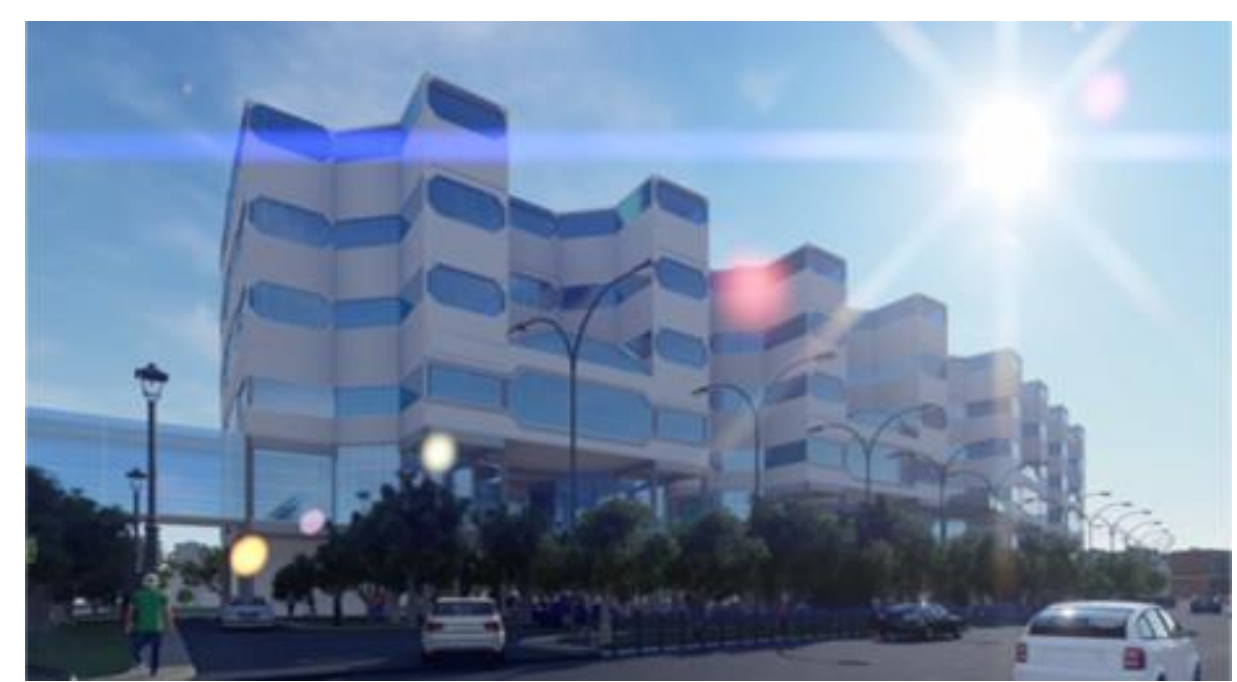

Gambar 13. Perspektif Exterior

Sumber: Penulis, 2019
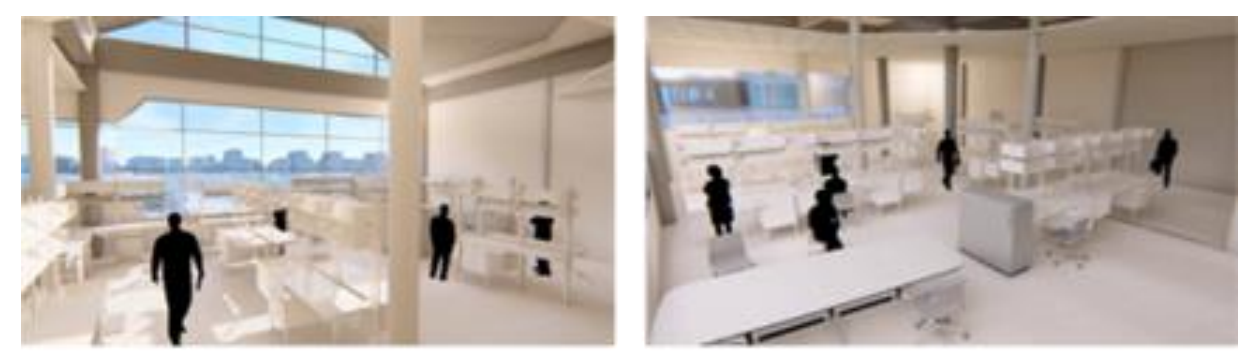

Interior Lab
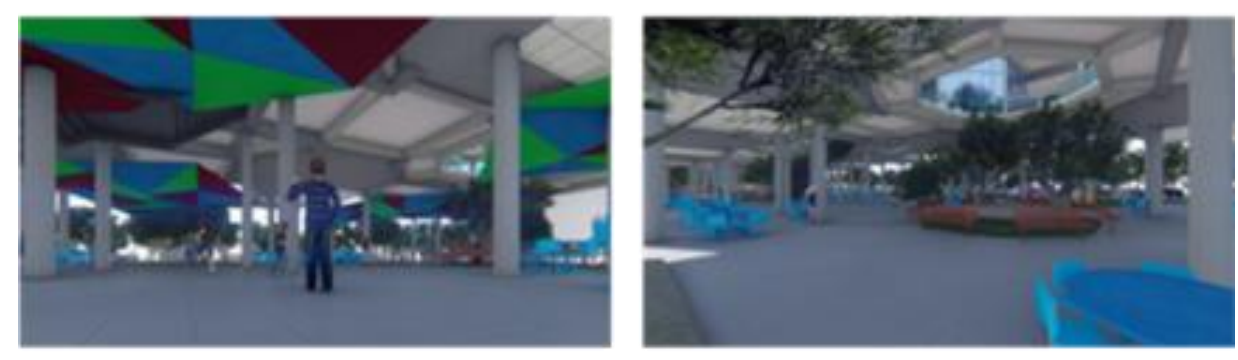

Interior Lobby

Gambar 14. Perspektif Interior

Sumber: Penulis, 2019

\section{KESIMPULAN DAN SARAN}

Kemajuan teknologi yang terjadi di generasi ini tidak bisa dipandang sebelah mata. Sebab tanpa kita sadari, kehadirannya secara perlahan dapat mengubah segala hal mendasar yang selama ini kita anggap sebagai hal yang biasa. Dengan memahami tentang karakteristik generasi milenial dan hubungannya dengan teknologi saat ini, kita akan dapat lebih mampu memahami kebutuhan, perilaku, serta karakteristik, dan dengan memfasilitasi penelitian, inovasi akan mampu tercapai dengan mengoptimalkan interaksi dan kolaborasi antar generasi ini maupun antar golongan lainnya. Pembangunan proyek ini diharapkan dapat menjadi solusi dalam menjawab perkembangan zaman di era digital ini dengan menciptakan sebuah fasilitas yang dapat menciptakan inovasi serta dapat memicu kewirausahaan yang baik serta mendorong para milenial untuk berkarya dan mencitakan inovasi untuk masa depan. 


\section{REFERENSI}

Babatunde,

A. (2011) Multidisciplinary Research Laboratory|Content http://www.uniosun.edu.ng/index.php/multidisciplinary-research-laboratory.html

Bahria University Medical \& Dental College (2016), Multidisciplinary Research - Academike https://www.lawctopus.com/academike/multidisciplinary-research/

Erickson, T.J. (2008). Plugged In The Generation Y Guide to Thriving at Work. Harvard Business Press: Boston.

Multidisciplinary Design Lab (MDL) I Villanova University https://www1.villanova.edu/villanova/engineering/undergrad/MDL.html

Multidisciplinary - Exilab(2019), https://www.exilab.com/en/multidisciplinary/

Haryadi dan Setiawan. (1995). Arsitektur Lingkungan dan Perilaku. Direktorat Jenderal Pendidikan Tinggi, Departemen Pendidikan dan Kebudayaan.

Hershatter, A. and Epstein, M. (2010). Millenials and the World of Work: An Organization and Management Perspective. Journal of Business Psychology

Tapscott, D. (2009). Grown Up Digital: How the Net Generation is Changing Your World. New York: McGraw-Hill.

Watch, D and Tolat, D. (2017), Research Laboratory | WBDG - Whole Building Design Guide https://www.wbdg.org/building-types/research-facilities/research-laboratory 